selection which differ slightly from those resulting from breeding experiments. Nevertheless, his results make it clear that the evolution of industrial melanism in $B$. betularia must depend in part on gene flow and on powerful non-visual selective forces whose nature is as yet unknown. There remain many other problems associated with this apparently straightforward example of natural selection. Why, for example, has the frequency of carbonaria decreased in northern England since the introduction of smoke control, but increased in the south ${ }^{7}$ ? Even for a melanic moth it seems that life is never as simple as made out in the textbooks.

\section{Acetylcholine receptor cloned east and} west and ... .

FurTHER to the article by C.F. Stevens (News and Views, 28 October 1982), it should be added that the cloning and 90 per cent of the sequence of the $\alpha$-subunit of the Torpedo acetylcholine receptor had already been reported by a group in Britain (K. Sumikawa, M. Houghton, J. Smith, L. Bell, B. Richards and E. Barnard Nucleic Acids Res. 10, 5809; 1982). The group used a two-stage procedure to design a 19-base oligodeoxyribonucleotide as an efficien hybridization probe in the cloning. From cDNA sequencing, the amino acid sequence of a 24-residue pre-N-terminal signal peptide and about 90 per cent of the sequence of the $\alpha$-subunit of the Torpedo marmorata receptor were determined. These sequences agree with the sequence for the $\alpha$-subunit of Torpedo californica since published by Noda et al. in Nature ( 28 October) and reviewed by Stevens. The only differences are at positions 42 (Asn for Ser), 230 (Val for Gly) and 318 (Asn for Asp), all single-base changes which are probably due to the species difference.

The mRNA fraction used has also been shown to be that for the native receptor by an exploitation of the oocyte translation system in which it forms the functional ion channel of the acetylcholine receptor $(E$. Barnard, R. Miledi and K. Sumikawa, Proc. R. Soc. B215, 241; 1982).

\section{Corrigendum}

In the News and Views article "A growing role for reverse transcriptase' (Nature 299, 204; 1982), reference was inadvertently omitted to a paper by S.Z. Hirschman, S.J. Vernace and F. Schaffner (Lancet 1, 1099; 1971), containing the first description of a DNA polymerase activity in preparations of human hepatitis B virus.

\title{
Pool and ridge patterns in peat mires
}

\section{from Peter D. Moore}

From the air, a peculiar pattern of concentric crescents can often be seen in the pools and ridges of a peat mire. The pattern stems from the tendency of pools on sloping mires to lengthen at right angles to the slope so that they run along the surface contours rather than downhill. But why should the peat pools grow in this manner?

Many theories have been put forward and it is possible that the causes of pool growth may differ according to the climatic environment of the mire and whether the mire surface is supplied with ground water or is dependent entirely on rainfall. Patterned peatlands are most frequent in high latitudes ${ }^{1}$, but they occur as far south as $55^{\circ} \mathrm{N}$ on the western fringes of Europe to about $46^{\circ} \mathrm{N}$ in Minnesota ${ }^{2}$, and they have recently been described as far south as $36^{\circ} \mathrm{N}$ in $\mathrm{Japan}^{3}$.

The boreal aapa mires occupy valleys and possess ridge and pool systems which traverse their entire width. It has been proposed that they owe their structure to ice pressure from the pool systems freezing in early winter ${ }^{4}$ but, although the freezing process could intensify a pattern once it has begun to form, it is doubtful whether this is the initial cause ${ }^{1}$. Snow cover may lead to a limited development of ice in winter in many Finnish mires, yet patterns are still apparent, as they are in the patterned mires of Japan, which also receive considerable snowfall in winter.

Study of Japanese mires led Sakaguchi to put forward a different theory for the origin of the patterns ${ }^{6}$. He claims that the initial generation of a bank/hollow complex could result from lines of accumulation of plant detritus - 'thatch lines' - carried by flood water over the mire surface. Interestingly enough the idea was considered in relation for Finnish mires in 1920 by Auer $^{4}$, but was not favoured by him. Sakaguchi backs up his proposals with observations on detritus patterns on sloping lawns after floods, which do indeed produce patterns which compare closely to those observed on a larger scale on sloping peatlands. It is an explanation which needs to be re-examined, preferably by detailed stratigraphical studies, in Finland.

Such a model is not satisfactory for the rain-fed raised and blanket mire pool patterns, for here the surface movement of water is restricted to local drainage requirements, there being no ground water supply. In these, the linear arrangement of pools again follow the contours of slope,

Peter D. Moore is a Senior Lecturer in the Department of Plant Sciences, University of London, King's College, 68 Half Moon Lane, London SE24 9JF. but in this case they are usually underlain by several metres of peat and the slope itself often results from the morphological features of the peat mass. The possibility that an entire body of peat may be unstable and moving gradually down slope was proposed by Troll $^{7}$ and developed by Pearsall ${ }^{8}$, who considered the sloping edges of a globular peat mass on a slope as a series of concentric pressure ridges.

The idea was put to the test by Pearson ${ }^{9}$ at Muckle Moss in Northumberland. As a result of detailed surveying of posts within the peat body from a fixed position beyond the mire, Pearson was able to show that some posts had moved by as much as 3-6 $\mathrm{mm}$ over a period of seven years. The mass movement of the peat was thus confirmed and the pool patterns at this site could be explained in terms of ruptures resulting from this stress. The explanation cannot be applied to all patterned peatlands, however, for the pool morphology does not always conform to that expected of peat ruptures. Pools are often shallow and frequently they develop on very gentle slopes.

Boatman, Grade and Hulme ${ }^{11}$ suggest that pools initially form in hollows which are related to irregularities in the underlying, sub-peat surface. They are then maintained by biological processes in which the peat accumulation rate is less in the vicinity of a pool than at some distance from it. The actual extent of the pools will then be related to surface water availability, one function of which is climate ${ }^{12}$. Some recently published stratigraphical work in Caithness, Scotland by Smart ${ }^{13}$, shows, however, that although pool systems may have a long history, they are not necessarily persistent in the sense that they retain specific positions and expand or contract from these ${ }^{14}$. So pool patterns may change in the course of time as the mire succession and peat accretion proceeds. Fortunately, that very accumulation of peat contains a detailed record of the history of the mire and further stratigraphical studies are the obvious way to find out how the peatland patterns emerge. $\square$

\footnotetext{
1. Sjörs, H. Endeavour 20, 217 (1961).

2. Heinselman, M. Ecol. Monogr. 33, 4 (1963)

3. Sakaguchi Y. Bull Dept. Geol. Univ. Tokyo 11, 17 (1979).

. Auer, V. Acta for. fenn. 12, 1 (1920).

Eurola, S. Ann. Bot. fenn. 12, 1 (1975)

Sakaguchi Y. Bull. Dept. Geol. Univ. Tokyo 12, 35 (1980)

Troll, C. Geol. Rundschav. 34, 545 (1944).

Pearsall, W.H. J. Ecol. 44, 493 (1966).

Pearson, M.C. J. Ecol. 48, 647 (1960).

0. Pearson, M.C. Acta Univ. Ouluensis A82, Geol. No.3, 65 (1979).

11. Boatman, D.J., Goode, D.A. \& Hulme, P.D. J.Ecol. 69, 897 (1981)

12. Barber, K.E. Peat Stratigraphy and Climatic Change (Balkena, Rotterdam, 1981).

13. Smart, P. J W Ecol 70, 549 (1982)

14. Walker, D. \& Walker, P.M. J. Ecol. 49, 169 (1961).
} 